\title{
The Institutional Settings of the Recovery of the NGO Sector in Post-Communist Countries
}

\author{
Halina Waniak-Michalak (iD) \\ Assistant Professor, Accounting Department, Management Faculty \\ University in Lodz, Poland, e-mail: halina.michalak@uni.lodz.pl
}

\section{Ivana Perica iD}

Senior lecturer, Department of Accounting and Auditing, Faculty of Economics Business and Tourism, University of Split, Croatia, e-mail: ivana.perica@efst.hr

\section{Sviesa Leitoniene (iD}

Associate Professor, Sustainable Economy Research Group

School of Economics and Business, Kaunas University of Technology, Lithuania e-mail: sviesa.leitoniene@ktu.lt

\section{Ewa Chojnacka iD}

Assistant Professor, Department of Financial Accounting

Nicolaus Copernicus University in Torun, Poland, e-mail: echoj@umk.pl

\section{Abstract}

The purpose of the paper is to describe the process of creating institutional settings in three post-communist countries and analyze the change of the social trust in these countries in line with the development of legal and accounting rules and norms for NGOs. The design and methodology include a literature analysis and the inductive method to analyze historical data for each country. The countries that were selected for the research are Lithuania - one of the Baltic states, which is in the last place in the World Giving Index (WGI) ranking, Poland with the average result in WGI ranking, and Croatia - the best post-communist country in the WGI ranking. Research limitations include the use of the descriptive method and the small number of countries included 
in the analysis. The originality and value of this paper lie in the fact that the problem of low social trust in NGOs in post-communist countries is analyzed by linking it with the development of NGO accountability and civil control over them.

Keywords: NGOs, post-communist countries, institutional theory, NGOs accountability, civil trust

JEL: M41, I31

\section{Introduction}

In communist countries after the end of World War II , the state took control of public benefit organizations for more than forty years. Social activity was destroyed; foundations' assets were nationalized, and their activities were prohibited. Years of communism made people mistrust all private actions and convinced them that it is state entities that are responsible for eliminating all social problems. The result today is that some citizens in post-communist countries are still not interested in helping others (Waniak-Michalak and Michalak 2016). As the level of public trust in post-communist countries is low (Wike 2008), public benefit activities are sometimes regarded suspiciously. After the end of communism, the lack of social capital, i.e., informal values and ethical norms common to people creating such organizations, was an obstacle to the development of non-governmental organizations (NGOs).

In order to build these ties, it was first necessary to increase people's trust before then starting cooperations and obtaining mutual benefits. One way to build trust was through self-regulation, control, and accounting regulations for NGOs. The purpose of the paper is to describe the process of creating institutional settings in three post-communist countries and to analyze the change of the social trust in these countries in line with the development of rules and norms for NGOs. Although institutional theory posits that institutions are made up of three pillars (regulative, normative, and cultural-cognitive), only the first one was used in our study. The following research questions were asked:

- How did the regulations for NGOs, the norms, and the rules in the chosen post-communist countries change in the 20 years after the end of communism?

- Are the scopes of the changes different or similar?

Did public trust in NGOs in post-communist countries change for the better?

To answer these questions, we used a literature analysis and the inductive method to analyze the historical data for the chosen countries: Lithuania - the European country in the last place in the World Giving Index ranking (2017), Poland with the average result in WGI ranking and Croatia - the first (the best) among all post-communist countries in the World Giving Index ranking (2018). 
We will analyze the period 2009-2017, because the CAF (Charities Aid Foundation) has not published the data for interviews conducted in 2018 in the report published in 2019.

Our paper is organized as follows. Firstly, the problem of regulations for NGOs and their development in light of institutional theory is discussed. In the second section, the development of the NGO sector, in comparison with public trust levels measured by the World Giving Index, is presented. Then the process of accounting regulations and control of NGOs in the three countries is presented in detail, and conclusions are drawn on the similarities and differences in the countries as well as the relationship between the social trust levels and their accounting regulations. Finally, the discussion and conclusions are presented.

\section{Institutional theory}

Institutions are sets of rules and practices, like formal and informal regulations, social norms and rules, shared understandings, and beliefs (Koster, Simaens \& Vos 2019). According to North (1990, p. 3), "Institutions are the rules of the game in a society or, more formally, are the humanly devised constraints that shape human interactions. In consequence, they structure incentives in human exchange, whether political, social, or economic." Institutional theory recognizes that it can shape the meaning and validity of social behavior (Scott, 2008). Williamson (2000), a proponent of new institutional economics, suggested four levels of social analysis. The higher level of social analysis imposes constraints on the lower level, but also, the lower level causes some feedback for the higher levels (Williamson 2000):

- Level 1: embeddedness (informal institutions, customs, traditions, norms, religion).

- Level 2: institutional environment (formal rules of the game - esp. property, polity, judiciary, bureaucracy).

- Level 3: governance (play of the game - esp. contract aligning governance structures with transactions).

- Level 4: resource allocation and employment (prices and quantities, incentive alignment).

New institutional economics concentrates mainly on levels 2 and 3 (Williamson 2000).

One of the essential characteristics of the socialist economy was that public administrations could interfere with companies and their relationships. The change of the economic system in the late 1980s and early 1990s required extensive institutional changes, including the change of fundamental legal rules. The possibility of the direct intervention of the administration was limited, and the role of legal norms increased significantly (Lissowska 2004, pp. 8-10). 
After the end of communism, most people did not believe in private activity, and cases of fraud at the beginning of the capitalist period did not improve the situation (Dąbrowska, Gumkowska and Wygnański 2002). Some NGOs were created not as a result of the growing interest of society in the problems of others (i.e., for altruistic reasons), but in order to commit fraud or run other activities that were contrary to the principles of social coexistence and the law.

Social behavior is shaped by the institutional context in which it takes place - faith or a lack of faith in private property, and regulating activities or not (Tolbert and Zucker 1996). However, social theory says that individuals always choose cost-benefit calculations (Coleman 1990; Hechter 1990). Therefore, the assumption that regulating NGO activities influences the social trust for them would be false.

Research conducted in post-communist countries shows that donors to NGOs do not use the financial information of NGOs to make decisions (Waniak-Michalak and Zarzycka 2015). Therefore, the decision to set financial reporting regulations for them was based on the global expectations of the accountability of all organizations. The politicians' approach to reforms and regulations was shaped by the political systems and institutions in other European countries. Poland, Lithuania, and Croatia, as EU members, were imposed to the influence of institutional settings of other European countries. The assumption that a state institution is autonomous was rejected by scientists in the 1980s when the theory of historical institutionalism was formed (Skocpol 1985). The evolution of existing institutions results from external factors (general operating conditions) that generate the possibility or need for new, better practices, or from pressure from groups interested in promoting institutional changes. As regards post-communist countries, there was a situation in which institutional continuity was broken, especially regarding formal norms and regulations. The nature of the transformation process, as a kind of imposed process, necessitated revolutionary changes, including the need to create a legal system that was adapted to the new political system, and which was influenced by institutions from other European countries (Lissowska 2004, pp. 60, 63-64).

Given the above, it was assumed that the chronology and scope of the regulations introduced for the activities and reporting of NGOs in post-communist countries were similar. We will try to prove this thesis in subsequent points of the article.

The same effect may appear in the NGO sector when some of them start to follow the rules and regulations. It is called isomorphism (Boxenbaum and Jonsson 2017). According to Powell and DiMaggio (1986), two types of isomorphism can be distinguished, competitive isomorphism and institutional isomorphism. Weber called competitive isomorphism the "cage of rationality" (Baehr 2001), pointing out that competitive processes force organizations to adopt similar forms and actions. Institutional isomorphism stems from (1) political changes and needs of greater legitimacy, (2) the response to uncertainty, and (3) the tendency for professionalization.

The more organizations are similar to their activities, the more isomorphic institutionalism deepens. The more NGOs prepare reports, the more reporting becomes in- 
stitutionalized. Isomorphism can be strengthened by standardizing reporting or making it compulsory. Problems arise when the stakeholders' expectations and behavioral patterns conflict with the interests of the organization. Then the phenomenon of decoupling (stratification) takes place, i.e., formally, the organization prepares financial statements, but they do not reflect what the organization does (MacLean and Behnam 2010). So, organizations are driven by, e.g., institutionalized products, services, techniques, policies, and the reporting system, which function as powerful myths. Organizations that become isomorphic with those myths of the institutional environment gain legitimacy, stability, and enhanced survival prospects (Meyer and Rowan 1977). The following sections of the article attempt to describe what NGOs' institutional isomorphism in accounting looks like in post-communist countries.

The institutions (norm, rules, regulations) support entities that cannot be responsible, accountable, or sustainable on their own. As research indicates, sustainability is not at the core of an NGOs' mission, and the way they act does not always follow the principles they advocate (Fassin 2009). Moreover, access to NGOs' financial data will not necessarily increase the rationality of decisions made by donors and NGO other stakeholders. People have a limited ability to analyze reality and make rational decisions. According to Herbert Simon, in some situations, it is unreasonable for people to analyze huge amounts of data to achieve maximum satisfaction. They conclude that the search for a perfect solution is, in itself, a costly activity. Therefore, people apply limited rationality - they save their time and effort, ultimately making decisions that are not perfect, but good enough (Krugman and Wells 2018). For example, they may decide to imitate others. If most people give money to a particular NGO, it may be enough to make a positive decision to support this NGO. This behavior is very similar in post-communist societies, where people tend to conform and imitate (Hodges 2014). Thus, the trust for NGOs can be built not by the contents of a financial statement but because the reporting and financial control of NGOs are obligatory.

\section{The historical background of non-profit organizations in Croatia, Poland, and Lithuania}

The earliest roots of civil society in Croatia can be traced to the work of brotherhoods that reached their peak in the early 1800s. The first written brotherhood statute was written in 1463, and it proves that, even then, these organizations did some of the things that would today be under the domain of civil society organizations (Draft National Strategy - Working Material for Counseling 2017). In Poland, before the First World War, charitable activities were run by Church organizations. Because of the partitions of both Poland and Lithuania, Polish society could not integrate and cooperate for the common good. That is why the first foundations or associations set up by members of society can be distinguished after World War I (Waniak-Michalak and Michalak 2016). 
According to Zalimienè and Rimšaite (2007), the participation of the non-governmental sector in the provision of social services in Lithuania also has old historical traditions (around the $15^{\text {th }}$ century). Members of parishes, dioceses, and religious and secular organizations (Caritas, Catholic Women's Society, Vincent Paulius, St. Nicholas, St. Zita, Lithuanian Women's Care, and other associations), established the first shelters for the elderly, the sick, and orphans. Until the first world war, the state was usually only a supporter of secular and Catholic non-governmental organizations that provided all basic social services. Organizations established homes for children and the elderly, and they took care of poor people, education, and caring for the sick. Members of the Catholic Women's Society of Lithuania even initiated the first training courses for social workers and tried to create the basis for a new profession; however, this never came to fruition due to the Second World War and Soviet occupation (Žalimienè and Rimšaitè 2007).

In Croatia, from the end of the $18^{\text {th }}$ century up to the 1950 s, the civil society developed through the growth of associations and societies that were funded by the initiatives of rich members of society. They founded and helped fund orphanages, hospitals, schools, and cultural institutions. These initiatives were also supported by the Catholic Church, which founded different organizations in order to help the poor (Bedžovan 2003b, p. 90). It was when associations and societies gradually formalized and started to make internal rules and statutes that defined membership, boards of directors, chairmen, and presidents (Draft National Strategy - Working Material for Counseling 2017).

In Poland, many associations and foundations were liquidated in on July 23, 1940, as a result of the order of Hans Frank, the governor-general of the occupied Polish territories (Kroll 1985). All associations in Poland had to stop their activity, and their property was confiscated.

According to Stasiukynas (2014), the breakthrough of community-based organizations, as well as the non-governmental, nonprofit sector in general, was associated with the proclamation of independence in Lithuania in 1918. In Lithuania, the number of NGOs grew before the Second World War. However, after the loss of independence, the situation changed, and civic initiatives were limited by the authorities (public organizations and cooperatives were left) (Šimašius 2007).

In Croatia, many foundations and humanitarian organizations were formed in the interwar period. After the Second World War, in all three countries, socialism was introduced, and freedom of society was limited. Foundations were nationalized or stopped existing. The state had complete control and monopolized all social services. The only exceptions were some associations that helped the sick or disabled, and the Church, which provided social aid and took care of the elderly and addicts through Caritas (the charity established by Church) (Bedžovan 2003b). In Poland, in 1952, with the power of the legal act, all private foundations and associations were liquidated, and their assets were seized by the government (Arczewska 2009). For many years, Polish citizens were taught that private organizations would only harm society and would 
serve only as a mechanism to steal and launder money. However, in the late 1970s, Poles noticed that the government's mechanisms had not managed to satisfy society's needs, so they began to create informal charitable organizations.

The Soviet period negatively affected the activities of non-governmental organizations not only in Lithuania but also in other post-Soviet republics. Only after the collapse of Communism did new opportunities for the development of civil society and NGOs open up. According to recent research in the former republics of the Soviet Union, the revival of civil society was made possible only by restoring national identity and mutual trust among citizens (Kèryte 2010).

More developed forms of civil society initiatives that were closer to the contemporary meaning of the term occurred in Croatia in 1982 with the introduction of the Law on social organizations and citizens' associations. That law served as a legal framework that made it legal to associate in such a manner. By 1985, 10,844 social organizations and 547 citizens' associations were officially registered (Draft National Strategy - Working Material for Counseling 2017).

In Poland, most associations and foundations also sprang up after the fall of communism. The first legal act regulating the activity of foundations in Poland was announced in 1984, and governmental control over these organizations was abolished. In 1997, 20,700 associations and 3400 foundations were registered.

Even though the roots of today's civil society can be found in different forms of social organization within the realms of the social-political paradigm established after World War II , the most significant development of civil society took place after 1991. It was at that time that the Republic of Croatia was formed as an independent country (Draft National Strategy - Working Material for Counseling 2017) and when Poland overthrew communism. The political changes of the time promoted freedom of assembly as a basic human right (Bedžovan 2003b).

After the restoration of independence of Lithuania in 1990, the mood of patriotism, nationality, and social initiatives took place. NGOs that had existed before the Second World War (such as the Scouts) were restored. Underground informal civic initiatives were legalized, and new organizations also emerged (e.g., "Social Service Volunteers," the LCCP "Step" and others). In reviewing the regulations of various public organizations established between 1992 and 1997, it can be argued that nationality, patriotism, assisting relatives, sobriety, and similar values were predominant (Stasiukynas and Žuromskaite 2014). It is noteworthy that financial support and other support were given by Western countries (Sweden, the United States of America) as a significant contribution to the development of NGOs and communities in Lithuania. The country was flooded with ideas and methods of new (unusual) activities. The meaningfulness of the public activities and the purposeful employment were realized by methods different from what had existed before, which was very attractive for young, proactive people. The non-governmental sector is considered to be one of the fastest developing sectors in Europe, including Lithuania. Two hundred and sixty public organizations were registered in Lithuania in 1995, while in 2005, the number had reached 
15,000. Various financial mechanisms have fostered and strengthened the NGO sector: PHARE (EU Program: Poland and Hungary: Assistance for Restructuring their Economies), and later mechanisms for strengthening the European Union and the European Economic Area.

Rural community support schemes had a significant influence on the development of rural communities. However, the number and activity of NGO organizations depend on the country's economic and political situation (Matonyte 2003). It should be emphasized that the slow development of non-governmental organizations in Lithuania was influenced by the political passivity of Lithuanian citizens (Kèryte 2010) and lack of authority (Guogis, Gudelis and Stasiukynas 2007). It needs to be noted that there is no single NGO statistical database in Lithuania, and a significant number of registered organizations do not carry out any activities. The main reason is that NGOs rely on volunteering, and there is no systematic financing of organizations in this field. Meanwhile, the official termination and de-registration of an organization requires additional resources (Stasiukynas 2014).

In Croatia, the first nonprofit organizations were formed during the Croatian War of Independence and the following refugee crisis in the early 1990s. It was at that time that many humanitarian organizations were founded and started collecting and distributing aid, providing shelter for refugees and other victims of war (Bežovan 2003a). They managed to successfully create a network with similar organizations in Europe, and they relied on many international humanitarian aid organizations. International organizations tend to be more effective if they have strong local organizations, and much of their work is to establish local self-managing organizations, which was also part of their exit strategy from Croatia (Bedžovan 2003b). The nonprofit sector in Croatia mainly developed with international aid in a time of crisis, mostly to manage problems that arose as a direct consequence of the war (Bedžovan 1995, p. 211). At that same time, numerous professional associations (psychologists, doctors, social workers) and other associations self-organized in solidarity with groups endangered by the war (Bedžovan 2003b). Many of these organizations received extensive humanitarian aid.

NGOs in Poland, Croatia, and Lithuania face a series of challenges: financial problems, a lack of skilled personnel, poor networking with other associations, insufficient cooperation with local counties and cities, a shortage of volunteers, prejudice against NGOs, and long-term planning, which proved to be difficult due to a change in donor requests (Bedžovan 2003a). Regardless of this fact, the non-profit sectors in these countries still is a sector whose potential is considerable.

According to the data from the Croatian Ministry of Public Administration on $31.12 .2017,52,244$ associations and 242 foundations were officially registered in Croatia. In Poland, there were 73,400 associations and 13,600 foundations, while the list of the Lithuanian State Enterprise Centre of Registers included 19,703 associations and 1005 foundations. A detailed comparison of the level of development of the nonprofit sector in Croatia, Poland, and Lithuania is shown in Table 1. 
The Institutional Settings of the Recovery of the NGO Sector in Post-Communist Countries

Table 1. The number of nonprofit organizations in Poland, Croatia, and Lithuania in 2017

\begin{tabular}{|l|c|c|c|c|c|c|}
\hline & Associations & Foundations & Total & $\begin{array}{c}\text { Associations } \\
\text { per 10,000 } \\
\text { inhabitants }\end{array}$ & $\begin{array}{c}\text { Foundations } \\
\text { per 10,000 } \\
\text { inhabitants }\end{array}$ & $\begin{array}{c}\text { Total per 10,000 } \\
\text { inhabitants }\end{array}$ \\
\hline Poland & 73900 & 14200 & 91000 & 19 & 4 & 23 \\
\hline Croatia & 52244 & 242 & 52486 & 125 & 1 & 126 \\
\hline Lithuania & 19703 & 970 & 20673 & 69 & 3 & 73 \\
\hline
\end{tabular}

Source: own elaboration based on data from the Statistical Offices in each country.

The number of charitable organizations in the three countries does not prove that there is a difference in the development of the sector (Table 1). The most active per 10,000 inhabitants is Croatia; however, further analysis of NGOs' revenues shows that the capacity measured donations from society is much lower in Poland and Croatia (Table 2). The analysis of NGOs in Lithuania is complicated because there is no official registry of the sector. It indicates the lower control over their activity in Lithuania and thus may be a sign of the lower development of the sector. Moreover, the lack of data may decrease public trust in NGOs.

Table 2. Revenues of NGOs in Poland, Croatia, and Lithuania in 2017

\begin{tabular}{|l|c|c|}
\hline & Annual gross income in EUR* & $\begin{array}{c}\text { Annual gross income in EUR/average } \\
\text { salary }\end{array}$ \\
\hline Poland** & $72,550.00$ & 6.22 \\
\hline Croatia & $26,878.00$ & 2.80 \\
\hline Lithuania & - & - \\
\hline
\end{tabular}

* Values of revenues in national currency were changed to EUR using the currency prices for the last day of the year

** the values are for 2016; data for 2017 were not available

Source: own elaboration based on data from the Statistical Offices in each country.

\section{Accountability, control, and public trust of NGOs}

\section{Accountability of NGOs}

Until 1994, there was no separate accounting system for non-profit organizations in Croatia. Until the Republic of Croatia gained its independence, all business entities were state-owned. Thus, until 1992, there was a single accounting system in Croatia characterized by uniform accounting. In 1993, the Law on Accounting introduced a dual accounting system, which compiles financial statements for external users but also financial reports according to tax laws. Those reports are then submitted to state institutions.

In Poland, the first Accounting Act was introduced in 1994. Before then, singular accounting and separate accounting regulations for different industries were used. 
The development of the nonprofit accounting sector in Croatia (shown in Table 3) started in 1994. In Poland the first act to regulate non-profit organizations that fulfill public benefit goals was issued in 2003, although the accounting rules for these organizations were prepared earlier, in 1998 (shown in Table 3), i.e., the Decree of the Ministry of Finance on accounting rules for some entities that are not trade companies and do not run a business activity. The Decree presented the structure of the balance sheet and income statement for these entities. Moreover, according to the rules, non-profit organizations did not have to follow the prudence principle. Later, in 2004, the Decree of the Ministry of Finance on the obligation of public benefit organizations to audit their financial statements was introduced. The goal was then to establish a system that would work with every specific organization from this sector.

In Lithuania, the activities of non-governmental organizations have been regulated since 1992, when the Government passed the Decree "On the Approval of the Basic Provisions of the Statutes of Non-profit Organizations (Enterprises)" (shown in Table 3). This legislation was the most important document regulating NGO activities, and it has defined the main principles of NGO activities and financing peculiarities for a long time. However, this Decree did not contain any provisions or requirements governing the accounting and financial reporting of NGOs. They were guided by general corporate accounting legislation, responses from tax administrations to individual inquiries, and creatively adjusting them to the specifics of NGO activities and funding.

Table 3. Accounting and other legal acts regulating the activity of NGOs in Croatia, Poland, and Lithuania in the years 1982-2008

\begin{tabular}{|c|c|c|c|}
\hline Year & Croatia & Poland & Lithuania \\
\hline 1982 & $\begin{array}{l}\text { Law on social organizations } \\
\text { and citizens' associations }\end{array}$ & & \\
\hline 1984 & & $\begin{array}{l}\text { Act on Foundations } \\
\text { regulating the creation, } \\
\text { activity, and reporting } \\
\text { of foundations }\end{array}$ & \\
\hline 1992 & Law of humanitarian aid & & $\begin{array}{l}\text { The Decree on the approv- } \\
\text { al of the basic provisions } \\
\text { of the statutes of non-prof- } \\
\text { it organizations }\end{array}$ \\
\hline 1993 & Accounting Act & & \\
\hline 1994 & $\begin{array}{l}\text { A separate accounting } \\
\text { system } \\
\text { Fund accounting } \\
\text { Modified accounting } \\
\text { principle }\end{array}$ & $\begin{array}{l}\text { Accounting Act, accrual } \\
\text { principle, and double } \\
\text { accounting introduced } \\
\text { for all entities }\end{array}$ & \\
\hline 1995 & & & $\begin{array}{l}\text { Law on Religious Communi- } \\
\text { ties and Associations, and } \\
\text { Law on Public Organiza- } \\
\text { tions }\end{array}$ \\
\hline
\end{tabular}


The Institutional Settings of the Recovery of the NGO Sector in Post-Communist Countries

\begin{tabular}{|c|c|c|c|}
\hline Year & Croatia & Poland & Lithuania \\
\hline 1996 & & & $\begin{array}{l}\text { Law on Charity and Spon- } \\
\text { sorship Funds, Law on As- } \\
\text { sociations, and Law on Pub- } \\
\text { lic Institutions }\end{array}$ \\
\hline 1998 & & $\begin{array}{l}\text { Decree of the Ministry } \\
\text { of Finance on detailed } \\
\text { accounting rules for some } \\
\text { entities that are not trade } \\
\text { companies and do not run } \\
\text { business activity }\end{array}$ & \\
\hline 1999 & $\begin{array}{l}\text { Establishment of the Gov- } \\
\text { ernment Office for Cooper- } \\
\text { ation with NGOs }\end{array}$ & & $\begin{array}{l}\text { The Order on the Financial } \\
\text { Accounting of Grants and } \\
\text { Subsidies }\end{array}$ \\
\hline 2003 & & $\begin{array}{l}\text { Law on public benefit activ- } \\
\text { ities and volunteering }\end{array}$ & \\
\hline 2004 & & $\begin{array}{l}\text { The Decree of the } \\
\text { Ministry of Finance on the } \\
\text { obligation of public benefit } \\
\text { organizations to audit their } \\
\text { financial statements } \\
\text { Activity reports are } \\
\text { obligatory. }\end{array}$ & $\begin{array}{l}\text { The Rules of Accounting } \\
\text { and the Financial Reporting } \\
\text { of Non-Profit Civil Liability } \\
\text { Legal Entities }\end{array}$ \\
\hline 2008 & $\begin{array}{l}\text { The accrual principle } \\
\text { Harmonizing with interna- } \\
\text { tional financial and statisti- } \\
\text { cal reporting } \\
\text { Accounting plan estab- } \\
\text { lished according to interna- } \\
\text { tional economic classifi- } \\
\text { cation } \\
\text { Harmonization with entre- } \\
\text { preneurial accounting }\end{array}$ & & \\
\hline
\end{tabular}

Source: own elaboration.

The first step in the non-profit sector accounting system in Croatia, Poland, and Lithuania was the introduction, between 1994 and 2008, of a dedicated accounting system that applied fund accounting and a modified accounting principle (Table 3 ). At the time, accounting for non-profit organizations was done according to the Decree on the accounting of non-profit organizations issued in Croatia in 1994 (based on the Law on accounting from 1992), in Poland in 1998, and in Lithuania in 1999.

In Poland, non-profit organizations could prepare their financial statements with the structure suggested by the Decree. It gave NGO managers general definitions of the revenues and costs of non-profit activities, but the rules of bookkeeping remained the same for all business and non-business units. To improve the accountability of Polish NGOs, in 2003, the Law on public benefit activity and volunteering was issued. The act introduced the obligation for public benefit organizations to prepare activity statements presenting the information not only on financial results but also employment, the number of volunteers, donations, and donors. 
In Lithuania, the first attempt to regulate the accounting of NGOs was the Order of the Minister of Finance of the Republic of Lithuania of 1999 on the Financial Accounting of Grants and Subsidies. It attempted to regulate the accounting of NGOs, but it did not meet the needs of NGOs. In 2004, in order to move to international accounting standards, the accounting of companies was reorganized, and it was decided to regulate the accounting of non-profit legal entities, including NGOs. In 2004, by order of the Minister of Finance of the Republic of Lithuania, the Rules of Accounting and Financial Reporting of Non-Profit Civil Liability Legal Entities were approved. They were to be applied by NGOs when preparing the 2005 financial statements. These rules have taken over the mandatory application of the accrual principle, as well as other accounting provisions that are recorded in the Business Accounting Standards.

The main provisions of the new accounting rules have indeed been considerably simplified compared to the Business Accounting Standards - they did not contain some requirements specific to profit-making companies. However, the problem is that the key feature of uniting all non-profit legal entities is to benefit the public performance, but their requirements were not fully reflected in the new accounting rules. Not taking into account the specifics of NGO activities caused several accounting and tax accounting problems. Until 2005, the goal of NGO accountability was the only one to correctly reflect the performance of NGOs in knowing the real situation. Since 2005, besides financial reporting (balance sheet, performance report, and notes), NGOs are also required to provide tax reporting. The purpose of this is to present performance results for tax purposes in accordance with the NGO tax legislation.

In Croatia, the next step in the development of the accounting system happened in 2008 with the introduction of the new Decree on non-profit organizations accounting that introduced many changes and, as a consequence, successfully harmonized it with entrepreneurial accounting and international financial and statistical reporting.

Table 4. Accounting and other legal acts regulating the activities of NGOs in Croatia, Poland, and Lithuania in the years 2009-2018

\begin{tabular}{|c|l|l|l|}
\hline Year & \multicolumn{1}{c|}{ Croatia } & \multicolumn{1}{c|}{ Poland } & \\
\hline 2009 & $\begin{array}{l}\text { Monitoring financial data of non- } \\
\text { profit organizations as a sector } \\
\text { General data on subjects and } \\
\text { data relevant for the database } \\
\text { of financial reports from } \\
\text { the Registry of non-profit } \\
\text { organizations become available } \\
\text { to the public according to the } \\
\text { ordinates of the Law on the } \\
\text { right to access information (the } \\
\text { exception being small, non-profit } \\
\text { organizations) }\end{array}$ & & \\
\hline
\end{tabular}


The Institutional Settings of the Recovery of the NGO Sector in Post-Communist Countries

\begin{tabular}{|c|c|c|c|}
\hline Year & Croatia & Poland & Lithuania \\
\hline 2010 & & & $\begin{array}{l}\text { Rules for the Accounting } \\
\text { and Financial Reporting } \\
\text { of Non-Profit Civil Liabil- } \\
\text { ity Legal Entities and the } \\
\text { Evaluation of the Assets } \\
\text { and Services of the Par- } \\
\text { ticipants of the Political } \\
\text { Company }\end{array}$ \\
\hline 2011 & & $\begin{array}{l}\text { Obligation to publish the fi- } \\
\text { nancial and activity report } \\
\text { on the government website }\end{array}$ & \\
\hline 2013 & & & $\begin{array}{l}\text { Law on the Development } \\
\text { of Non-governmental } \\
\text { Organizations }\end{array}$ \\
\hline 2014 & & $\begin{array}{l}\text { NGOs are obliged to fulfill } \\
\text { the regulations of the Ac- } \\
\text { counting Act as other en- } \\
\text { tities. However, they can } \\
\text { prepare simplified financial } \\
\text { statements if they do not } \\
\text { run a business activity. }\end{array}$ & \\
\hline 2015 & $\begin{array}{l}\text { The Law on Financial Operations } \\
\text { and Accountancy of Non-Profit } \\
\text { Organizations came into force } \\
\text { The obligation to self- } \\
\text { assess financial management } \\
\text { and to enforce control. } \\
\text { The obligation to make plans for } \\
\text { large non-profit organizations } \\
\text { The obligation to create financial } \\
\text { reports } \\
\text { All financial reports made public } \\
\text { through the Registry of non- } \\
\text { profit organizations }\end{array}$ & $\begin{array}{l}\text { Law on public benefit } \\
\text { activity and volunteering- } \\
\text { full and simplified activity } \\
\text { reports. Some NGOs } \\
\text { do not have to prepare } \\
\text { financial statements }\end{array}$ & $\begin{array}{l}\text { Obligation to submit } \\
\text { financial statements } \\
\text { to the State Enterprises } \\
\text { "Center of Registers" } \\
\text { and "Statistics Lithuania." }\end{array}$ \\
\hline 2017 & & $\begin{array}{l}\text { Creation of the National } \\
\text { Institute of Freedom - the } \\
\text { Center of Civil Socie- } \\
\text { ty Development, which } \\
\text { is responsible for the dis- } \\
\text { tribution of grants and in- } \\
\text { formation on NGOs }\end{array}$ & \\
\hline 2018 & & & $\begin{array}{l}\text { Changing the Rules for } \\
\text { the Accounting and } \\
\text { Financial Reporting } \\
\text { of Non-Profit Civil Liabil- } \\
\text { ity Legal Entities and for } \\
\text { the Evaluation of the As- } \\
\text { sets and Services of the } \\
\text { Participants of Political } \\
\text { Companies }\end{array}$ \\
\hline
\end{tabular}

Source: own elaboration. 
In the case of Lithuania, The Rules of Accounting and Financial Reporting of Non-Profit Civil Liability Legal Entities were adjusted in 2010 (shown in Table 4). These rules were extended to include an evaluation of the assets and services of the participants of political companies. In 2015, NGOs were obliged to submit their financial statements to the Center of Registers. This somewhat increased the transparency of their activities, as these reports could be bought at the Registry Center. In 2018, the accounting rules of NGOs changed again, and NGOs were allowed to use simplified accounting.

\section{Control over NGOs}

As doubts about the misuse of humanitarian aid leaked into the public domain, in 1992, the Croatian government issued the Law of humanitarian aid. The government also founded a commission to monitor humanitarian organizations, to monitor and stop the processes of resale and the unlawful use of humanitarian aid (Bedžovan 2003b).

In Poland, since 2018, the Director of the National Freedom Institute has control over NGOs; previously, the task was performed by the Ministry of Work and Social Policy. According to the "Law on public benefit activity and volunteering," all charitable organizations with the status of public benefit organizations must publish their financial statements. If they do not fulfill the requirement, they may lose the status of a public benefit organization.

The Decree of the Government of the Republic of Lithuania, "On the areas of management entrusted to ministers," stipulates that the Ministry of Social Security and Labor is responsible for managing the development of communities and non-governmental organizations. One of the objectives of the Ministry of Social Security and Labor is to formulate the development policy of communities and non-governmental organizations, to organize, coordinate, and control its implementation. Meanwhile, the Authority of Audit, Accounting, Property Valuation, and Insolvency Management (under the Ministry of Finance) monitors the accounting of NGOs to ensure the reliability of financial reporting information.

In order to increase transparency in the work of associations and under some international pressure, the Croatian Government established the Government Office for Cooperation with NGOs in 1999, which significantly contributed to the transparent allocation of funds allocated to NGOs from the state budget (Bežovan, Zrinščak and Vugec 2005).

The same was done in Poland, but in 2017. In September of that year, the National Institute of Freedom - the Center for Civil Society Development was set up to support the development of civil society in Poland. The Institute receives government grants and allocates the money in projects carried out by nonprofit organizations in Poland.

Meanwhile, in Lithuania, the Commission for the Coordination of Non-Governmental Organizations' Affairs was established in 2010. It consists of representatives from state institutions, municipalities, and non-governmental organizations. The main functions of the Commission are to put forward proposals to the Government on leg- 
islation regulating the activities of non-governmental organizations and on the development of new legislation; the development of cooperation between the state, municipal institutions and institutions, and non-governmental organizations; and the implementation of measures for the development of non-governmental organizations. In 2014, the activities of the commission were taken over by the Council of Non-Governmental Organizations.

\section{Public trust in NGOs and their level of accountability}

An important issue for NGOs operating in post-communist countries is the persistently low level of public trust in them (Waniak-Michalak and Zarzycka 2013; Borowiecki and Dziura (eds) 2014; Waniak-Michalak \& Michalak 2016). For example, in Poland and Lithuania, 26 years after the fall of communism, society believes neither in the honesty nor in the effectiveness of NGOs. Research by the Klon-Jawor Association in Poland proves that the trust of Polish citizens in NGOs decreased in both 2014 and 2016. Almost $50 \%$ of respondents believed that NGOs embezzle the money they receive. One of the reasons for the low civil trust may be the lack of tools to evaluate NGOs, like the Charities Navigator in the USA or the website of the Charity Commission in the UK.

In the case of Poland and Lithuania, however, the only possibility for donors to evaluate an NGO's achievements is to analyze their financial statements themselves. Unfortunately, many donors do not have the skills or time for it, or, if they do, they find that the financial statements are of low quality (Ling and Gordon 2013). According to some researchers, accountability matters (Agyemang et al. 2009). Howard (2003) contends that post-communist countries have lower levels of organizational membership than democracies and other post-authoritarian states, with the weakness of civil society in the region stemming from the mistrust of the previous communist organizations, the persistence of personal contacts over community ones, and widespread disappointment with the reforms undertaken in the early post-communist era.

Faith in the non-profit sector has been questioned as a result of several high-profile scandals, prompting increasing calls for transparency. Discrepancies between what NGOs say and do are noticed and analyzed in research studies and papers (Epperly and Lee 2015; Gray, Bebbington and Colisson 2006; del Mar Gálvez-Rodríguez et al. 2014). At the same time, there is a significant gap in the research on NGO accountability and state control over them. It should be noted believe that before implementing regulations to control NGOs, an investigation should be carried out into whether they are required and, if so, what form they should take.

A few empirical studies conducted by various international and national NGOs can be found that cover NGO accountability and transparency. For example, Transparency International (2008) surveyed 605 Lithuanian NGOs concerning their goals and performance, accountability, and transparency issues. $66.9 \%$ of respondents asserted that NGOs are transparent, while $26.6 \%$ believe the opposite. Information disclosure of financial accountability to the public is evaluated the lowest - only $9 \%$ of respond- 
ents believe that public accountability of NGOs is acceptable. These research results are consistent with the results of other research related to financial information disclosure and transparency. Below is a graph of the public trust indices in Poland, Lithuania, and Croatia.

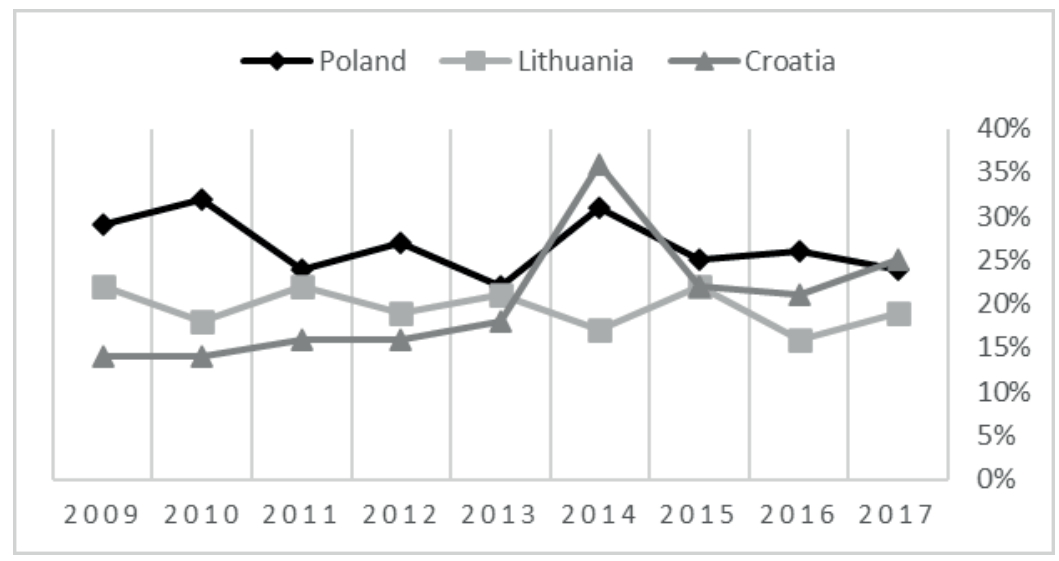

Chart 1. The civil trust in Poland, Lithuania, and Croatia in the years 2009-2017 Source: own elaboration of data of Charities Aid Foundation.

According to the research of the Charities Aid Foundation, social trust for NGOs increased in 2014 in some countries, mainly as a result of natural disasters (flooding in Croatia) or wars. At the time, people decided to make donations, not to a specific organization but for a specific purpose. It should also be noted that in 2015, two fundamental legal acts were introduced in Poland and Croatia. However, their effect would be expected in the next year or later when new financial statements of NGOs would be prepared.

In 2015, a further decline in social trust for NGOs can be observed in Poland. During this period, the conservative political party PIS gained a majority in the government, and it started to run a campaign against non-governmental organizations. PIS party members made allegations of misappropriation of public funds and fraud committed by NGOs, and as a result, some citizens turned against NGOs. One of the reasons for the government's attitude was its unwillingness to accept refugees. Therefore, it did not want to finance activities that aimed to support or integrate refugees, that supported human rights, or that aimed to give different minority groups the right to equal treatment, among others. This stance awakened a strong institution in Poles, intolerance, which became a tool to fight against NGOs and civil society. Therefore, the public trust for NGOs in Poland is even lower than in 2009, before all the most critical changes in legal requirements, including accounting rules, for NGOs.

In other countries, the lack of institutional mechanisms (imposed on citizens by the state as a social obligation) resulted in a decline in charity. In Poland, a $1 \%$ income tax mechanism was introduced in 2004. Initially, if Polish taxpayers wanted to make a contribution, they had to make their payments to selected non-governmental or- 
ganizations and then show the amount of the donation as an item that was deductible from their income tax. However, it turned out that Poles were not ready to accept such a duty. It was not their business, and it required too much effort. Therefore, in 2007, a change was introduced in the way taxpayers transferred the $1 \%$. Since then, taxpayers only have to indicate on their tax statement to whom they want to transfer the $1 \%$, and the money is transferred by the tax authorities. In the following year (2008), this change resulted in four million more taxpayers making deductions to a charity.

Lithuania has the lowest level of public trust. Markšaitytè et al. (2017) point to the link between social trust in Lithuania and the low level of happiness of Lithuanians. Their lack of faith in the possibility of improving their well-being discourages Lithuanians from helping others. The compulsory reporting by non-governmental organizations (NGOs) to the Center of Registers (2015) only temporarily increased public trust in NGO organizations in 2015. In 2016, trust levels fell again. And while changing the rules for the accounting and financial reporting of NGOs in 2017 increased the transparency of these organizations, it takes time. Therefore, the problem of the low trust in NGOs will not be solved only by increasing the accountability of NGOs.

\section{Conclusions}

Philanthropic activities had early beginnings in the three countries (Poland in the $12^{\text {th }}$ century, and both Croatia and Lithuania in the $15^{\text {th }}$ century), but this did not result in the creation of social capital or trust in charity organizations. The experience of the communist regime was of great importance. In all three countries, the re-development of NGOs generally followed the fall of communism. Since the early 1990s:

- The introduced legal rules were intended to constitute a formal basis for the development of NGOs, in the absence of acquired and established social norms.

- The formal institutions that determined the development of NGOs are the introduction of laws, including the regulation of accounting for NGOs, access to reports, and the introduction of a supervisory body.

The institutional changes in the NGO sector in the analyzed countries followed the same path. However, their scope is different, and it is difficult to link the scope of the introduced regulations with the observed social trust in the analyzed countries. The fastest legal changes were introduced in Croatia:

- Accounting law for NGOs - 1994,

- Access to NGO reports - 2008,

- Control Body - the Croatian Government established the Government Office for Cooperation with NGOs in 1999.

However, this did not result in a high level of trust. In 2010, it was the lowest in comparison to Poland and Lithuania (one of the limitations of the study is that there are no trust data before 2010). 
Changes in Poland took place a bit later:

- Accounting law for NGOs - 1998,

- Access to NGO reports (only public benefit organizations) - 2011,

- The creation of the National Institute of Freedom - Center of Civil Society Development - 2017 .

Despite the slower institutional development of the Polish NGO sector, social trust in NGO activities has been higher than in Croatia since 2010.

The social trust in NGOs is lower in Lithuania compared to the situation in Poland since 2010 and to Croatia since 2015, although the development of the institutional environment is similar in all countries:

- Lithuanian Accounting law for NGOs - 1999 (but more important changes came in 2003),

- Access to NGO reports in 2015 - obligation to publish,

- Inspection body - in 2010, the Commission for the Coordination of Non-Governmental Organizations Affairs was established.

It is important to note that in Lithuania, NGOs' financial reports have become available to the public only since 2015, and, initially, they were only available for purchase from the State Enterprise "Centre of Registers." Since 2018, this information is free.

The assumption that regulating NGOs' activities influences the social trust for them has not been proven. However, it can be assumed that recent legal and accounting changes in NGO activities may increase social trust in these organizations' activities. It will take time and will depend on the quality of the implementation of these reforms. For this reason, in the future, it would be useful to extend the research by analyzing the period from 2018 onwards. In addition, it would be useful to analyze a greater number of post-communist countries in any further investigation.

\section{References}

Agyemang, G., Awumbila, M., Unerman, J., O’Dwyer, B. (2009), NGO accountability and aid delivery, The Association of Chartered Certified Accountants. https://core .ac.uk/download/pdf/13120503.pdf (accessed: 18.03.2020)

Baehr, P. (2001), The "Iron Cage" and the "Shell as Hard as Steel": Parsons, Weber, and the Stahlhartes Gehäuse Metaphor in the Protestant Ethic and the Spirit of Capitalism, "History and Theory", 40 (2), pp. 153-169. http://www.jstor.org/stable/2678029 (accessed: 18.03.2020)

Bežovan, G. (1995)., Neprofitne organizacije i kombinirani model socijalne politike [Non-profit organizations and the combined model of social policy], "Revija za socijalnu politiku”, 2 (3), pp. 195-214. https://doi.org/10.3935/rsp.v2i3.515

Bežovan, G. (2003a), Razvoj organizacija civilnog društva kao pretpostavka uspješne reforme socijalne države u Hrvatskoj [Development of civil society organizations 
as a precondition for successful reform of the welfare state in Croatia], "Politička misao", 40 (01), pp. 72-91.

Bežovan, G. (2003b), Preispitivanje okvira i potencijala za razvoj kombinirane socijalne politike u Hrvatskoj [Reviewing the Framework and Potential for the Development of Combined Social Policy in Croatia], "Socijalna ekologija: časopis za ekološku misao i sociologijska istraživanja okoline”, 12 (1-2), pp. 87-108.

Bežovan, G., Zrinščak, S., Vugec, M. (2005), Civilno društvo u procesu stjecanjapovjerenja u Hrvatskoj i izgradnje partnerstva s državom i drugim dionicima [The civil society in Croatia: the process of gaining trust and establishing partnership with the state and other stakeholders]. (Croatia report), Centre for Development of NonProfit Organizations (CERANEO), Croatia, Zagreb.

Borowiecki, R., Dziura, M. (2014), Third Sector: Theoretical and Empirical Approach, Cracow University of Economics, Cracow.

Boxenbaum, E., Jonsson, S. (2017), Isomorphism, diffusion and decoupling: Concept evolution and theoretical challenges. , [in:] R. Greenwood, C. Oliver, T. Lawrence and R.E. Meyer (eds), The Sage handbook of organizational institutionalism, $2^{\text {nd }}$ Ed., pp. 79-104, Sage Publications, London. https://www.researchgate.net/profile/Stefan _Jonsson4/publication/279755008_Isomorphism_Diffusion_and_Decoupling/lin ks/563f936708ae8d65c0150efb/Isomorphism-Diffusion-and-Decoupling.pdf (accessed: 18.03.2020).

Coleman, J.S. (1990), Foundations of social theory, Belknap Press of Harvard University Press, Cambridge MA.

del Mar Gálvez-Rodríguez, M., Stuart, D., Caba-Perez, C., López-Godoy, M. (2014), Drivers for the proactive online disclosure of information in the NGO sector: the Colombian case, „Online Information Review”, 38 (6), pp. 769-787. https://doi.org/10 .1108/OIR-05-2014-0113

Epperly, B., Lee, T. (2015), Corruption and NGO sustainability: A panel study of post-communist states, "Voluntas", 26 (1), pp. 171-197. https://doi.org/10.1007/s1 1266-013-9404-3

Fassin, Y. (2009), Inconsistencies in activists behaviours and the ethics of NGOs, "Journal of Business Ethics”, 90 (4), pp. 503-521. https://doi.org/10.1007/s10551-009-0056-6

Gray, R., Bebbington, J., Colisson, D. (2006), NGOs, Civil Society and Accountability: Making the People Accountable to Capital, "Accounting Auditing \& Accountability Journal”, 19 (3), pp. 319-348. https://doi.org/10.1108/09513570610670325

Guogis, A., Gudelis, D., Stasiukynas, A. (2007), The importance of the NGO-municipal relations in developing local democracy: case study of two Lithuanian municipalities, "Public Policy and Administration", 1 (22), pp. 47-56. https://doi.org/10.1007 /s12208-008-0004-7

Hechter, M. (1990), Social Institutions: their Emergence, Maintenance, and Effects, Aldine de Gruyter, New York.

Hodges, B.H. (2014), Rethinking conformity and imitation: Divergence, convergence, and social understanding, "Frontiers in psychology", 5, pp. 1-11. https://doi.org/10 .3389/fpsyg.2014.00726

Howard, M.M. (2003), The Weakness of Civil Society in Post-Communist Europe, Cambridge University Press, Cambridge. https://oi.org/10.1017/CBO9780511840012 
Kèrytè, Ž. (2010), Pilietiškumo konstravimas globalumo kontekste: NVO vaidmens kaita Lietuvoje [Construction of Citizenship in a Global Context: The Change of NGOs" Role in Lithuania], "Kultūra ir visuomenè: socialinių tyrimų žurnalas", 1 (2), pp. 67-83.

Koster, M., Simaens, A., Vos, B. (2019), The advocate's own challenges to behave in a sustainable way: An institutional analysis of advocacy NGOs, "Journal of Business Ethics”, 157 (2), pp. 483-501. https://doi.org/10.1007/s10551-017-3674-4

Kroll, B. (1985), Rada Główna Opiekuńcza: 1939-1945 [Central Welfare Council: 1939-1945], Książka i Wiedza, Warszawa.

Krugman, P. Wells, R. (2018), Macroeconomics.U.S.: Worth Publishers Inc.

Law on Financial Operations and Accountancy of Non-Profit Organizations, "Official Gazette of the Republic of Croatia”, 121 (2014), 30.

Leś, E. (1994), The voluntary sector in post-communist East Central Europe: From small circles of freedom to civil society, CIVICUS-World Alliance for Citizen Participation, Washington.

Leś, E. (2001), Zarys historii dobroczynności i filantropii w Polsce, Prószyński i S-ka, Warszawa.

Leś, E., Nałęcz, S., Pieliński, B. (2016), Third sector barriers in Poland (TSI National Report Series, No. 7, Seventh Framework Programme - grant agreement 613034), European Union, Brussels: Third Sector Impact.

Ling, Q., Gordon, N.D. (2013), Journal of Public Budgeting, "Accounting \& Financial Management”, 25 (1), pp. 69-90. https://doi.org/10.1108/JPBAFM-25-01-2013-B004

Lissowska, M. (2004), Instytucjonalne wymiary procesu transformacji w Polsce [Institutional dimensions of the transformation process in Poland], Szkoła Głowna Handlowa, Warsaw.

MacLean, T.L., Behnam, M. (2010), The dangers of decoupling: The relationship between compliance programs, legitimacy perceptions, and institutionalized misconduct, “Academy of Management Journal”, 53 (6), pp. 1499-1520. https://doi.org/10 .5465/amj.2010.57319198

Marksaityte, R., Žardeckaitè-Matulaitienè, K., Seibokaite, L., Endriulaitiene, A. (2017), The importance of social trust for the prediction of well-being of Lithuanians and Lithuanian emigrants, "International Journal of Psychology", 21, pp. 71-92. https://doi .org/10.7220/2345-024X.21.4

Matonytè, I. (2003), Theoretical Approaches in Civil Society Research, "Public Policy and Administration", 1 (5), pp. 39-47.

Meyer, J.W., Rowan, B. (1977), Institutionalized organizations: Formal structure as myth and ceremony, "American journal of sociology", 83 (2), pp. 340-363. https://doi.org $/ 10.1086 / 226550$

Ministry of Finance (2018), Registry of non-profit organizations. https://banovac.mf in.hr/rnoprt/ (accessed: 18.03.2020)

Nacrt Nacionalne strategije - radni materijal za savjetovanje : nacionalna strategija stvaranja poticajnog okruženja za razvoj civilnoga društva od 2017. do 2021. [Draft National Strategy - Working Material for Counseling A National Strategy for Creating an Enabling Environment for Civil Society Development from 2017 to 2021]. (2017). https://esavjetovanja.gov.hr/ECon/MainScreen?entityId=5697 (accessed: 18.03.2020) 
North, D. (1990), Institutions, Institutional Change and Economic Performance, Cambridge University Press, Cambridge. https://doi.org/10.1017/CBO9780511808678

Powell, W.W., DiMaggio, P.J. (1986), The Iron Cage Revisited: Institutional Isomorphism and Collective Rationality in Organizational Fields, "American Sociological Review", 48 (2), pp. 147-160. https://doi.org/10.2307/2095101

Scott, W.R. (2008), Institutions and organizations: Ideas and interests, Sage Publications, Los Angeles.

Skocpol, T. (1985), Bringing the State Back In: Strategies of Analysis in Current Research., [in:] P.B. Evans, D. Rueschemeyer, T. Skocpol (eds), Bringing the State Back In, 3-38, Cambridge University Press, New York. https://doi.org/10.1017/CBO978 0511628283.002

Stasiukynas, A. (2014), Traditions and Management Perspectives of Community and Non-Profit Organizations in Lithuania, "Social Technologies", 4 (2), pp. 370-384. https://doi.org/10.13165/ST-14-4-2-10

Stasiukynas, A., Žuromskaitè, B. (2014), Jaunimo nevyriausybinès organizacijos LKJBS „Žingsnis“ vertybés - sékmingos veiklos pagrindas, [in:] A.G. Raišienè (eds), Veiksmingos vadybos gairès: teorinés ǰžvalgos ir Lietuvos organizacijų atvejai, 144-177, Mykolo Romerio universitetas, Vilnius.

Šimašius, R. (2007), Ne pelno organizacijos: prigimtis ir reglamentavimas, Leidykla Eugrimas, Vilnius.

Tolbert, P.S., Zucker, L.G. (1996), The Institutionalization of Institutional Theory. https://digitalcommons.ilr.cornell.edu/cgi/viewcontent.cgi?article=1430\&context $=$ articles (accessed: 18.03.2020)

Waniak-Michalak, H., Michalak, J. (2016), Corporate and NGOs Voluntary Disclosure on Collaboration. Evidence from Poland, "Inzinerine Ekonomika-Engineering Economics”, 27 (1), pp. 98-108. https://doi.org/10.5755/j01.ee.27.1.9338

Williamson, O.E. (2000), The new institutional economics: taking stock, looking ahead, "Journal of Economic Literature", 38 (3), pp. 595-613. https://doi.org/10.1257/jel.38 .3 .595

Žalimienè, L., Rimšaite, E. (2007), The metamorphosis of the role of nongovernmental organizations - from charity in XVIII century to market of social services in modern society, "Social Work", 6 (1), pp. 83-95. 


\section{Streszczenie}

\section{Uwarunkowania instytucjonalne w rozwoju sektora organizacji pozarządowych w krajach postkomunistycznych}

Celem artykułu jest analiza procesu tworzenia otoczenia instytucjonalnego sektora organizacji pozarządowych w trzech wybranych krajach postkomunistycznych oraz analiza zmian zaufania społecznego $w$ tych krajach w odniesienu do zmian norm prawnych i rachunkowości dla organizacji pozarządowych. Metodologia badań obejmuje analizę literatury i indukcyjną metodę analizy danych historycznych dla wybranych krajów postkomunistycznych. Do badań wybrano trzy kraje postkomunistyczne: Litwę - jeden z krajów bałtyckich, zajmujący ostatnie miejsce w rankingu World Giving Index, Polskę i Chorwację - dwa najlepsze kraje postkomunistyczne w rankingu World Giving Index. Ograniczenia badawcze wynikają z zastosowania metody opisowej i niewielkiej liczby krajów objętych analizą. Oryginalność i wartość niniejszego opracowania polega analizie problemu niskiego zaufania społecznego do organizacji pozarządowych w krajach postkomunistycznych w kontekście rozwoju otoczenia instytucjonalnego organizacji pozarządowych oraz wzrostu ich rozliczalności i cywilnej kontroli nad nimi.

Słowa kluczowe: World Giving Index, kraje postkomunistyczne, organizacje pozarządowe, teoria instytucjonalna, rachunkowość 